\title{
Enzymatic Studies on the Conversion of Erythritol Fermentation to D-Mannitol Fermentation in n-Alkane-grown Yeast Candida zeylanoides
}

\author{
Kiyoji HatTori and Takeo Suzukı \\ Tokyo Research Laboratory, Kyowa Hakko Kogyo Co., Ltd., \\ Machida, Tokyo
}

Received June 6, 1974

\begin{abstract}
In the polyol fermentation by Candida zeylanoides KY6166, which occurred preferentially by keeping the $\mathrm{pH}$ of medium at acidic side (below 4.0), phosphate ion played a precise role in the conversion of erythritol fermentation to D-mannitol fermentation. Enzymatic studies on the conversion mechanism provided the following evidences.

The enzymes involved in pentosephosphate cycle were considerably depressed in polyol production phase in which intracellular $\mathrm{pH}$ ranged from 5.5 to 5.7. Particularly transaldolase responsible for the synthesis of erythrose 4-phosphate and fructose 6-phosphate from glyceraldehyde 3-phosphate plus D-sedoheptulose 7-phosphate was significantly depressed at $\mathrm{pH}$ 5.5. Besides, transketolase which participated directly in the formation of erythrose 4-phosphate from fructose 6-phosphate was significantly inhibited by phosphate ion. Glucose 6-phosphate dehydrogenase was slightly inhibited by phosphate ion.

From these results, the alteration from erythritol fermentation to mannitol fermentation by phosphate ion was explained as the result of the change in the level of erythrose 4phosphate and fructose 6-phosphate which was caused by the inhibition of transketolase.
\end{abstract}

In the enzymatic study on polyol production by citric acid producer, ${ }^{4}$ Candida zeylanoides KY6166, the primary cause of the conversion of citric acid fermentation to erythritol fermentation was explained by the depression citrate synthase and the activation of phosphoenolpyruvate carboxykinase by the change of intracellular $\mathrm{pH}$ from 6.7 to 5.5 according to the change of the $\mathrm{pH}$ of the medium from 5.5 to 3.5 .

On the other hand, under the established condition for polyol production, the shift of phosphate ion concentration in the culture medium led to the conversion of erythritol production to mannitol production. ${ }^{2 \text { ? }}$

This phenomenon has not been observed in the production of polyols from carbohydrate sources. Thus, it was of great interest to investigate the enzymatic relations underlying the conversion mechanism.

This paper deals with the effect of $\mathrm{pH}$ and phosphate ion on the activities of enzymes involved in pentosephosphate cycle which closely related with polyol interconversion.

\section{MATERIALS AND METHODS}

Microorganisms. Candida zeylanoides KY6166 was employed throughout this study, Other strains were also employed partly to compare with above organism. All the strains were kindly supplied by Mr. Takayama et al. in this laboratory.

Media and culture conditions. The composition of the medium was as follows; $n$-alkane mixture (C-12 to $\mathrm{C}-15), 10 \%(\mathrm{w} / \mathrm{v}) ; \mathrm{KH}_{2} \mathrm{PO}_{4}, 0.03 \% ; \mathrm{MgSO}_{4} \cdot 7 \mathrm{H}_{2} \mathrm{O}$, $0.05 \%$; ammonium sulfate, $0.5 \%$; thiamine- $\mathrm{HCl}, 1 \mathrm{mg} /$ liter; $\mathrm{MnSO}_{4} \cdot 7 \mathrm{H}_{2} \mathrm{O}, 2 \mathrm{mg} / \mathrm{liter} ; \mathrm{ZnSO} \cdot 7 \mathrm{H}_{2} \mathrm{O}, 2 \mathrm{mg} /$ liter; $\mathrm{CuSO}_{4} \cdot 5 \mathrm{HO}_{2}, 50 \mu \mathrm{g} /$ liter; in tap water. The $\mathrm{pH}$ was adjusted to 5.0 before sterilizing. The yeast was grown in a 5 -liter fermentors containing 3 liters of the culture medium with agitation at $600 \mathrm{rpm}$ and aeration of 3 liters per minute at $30^{\circ} \mathrm{C}$. In each run, the inoculum $(300 \mathrm{ml})$ was cultured in the seed medium for $30 \mathrm{hr}$ at $30^{\circ} \mathrm{C}$ on a rotary shaker $(220 \mathrm{rpm})$, which was composed of $n$-alkane mixture $(\mathrm{C}-12$ to $\mathrm{C}-15), 5 \%(\mathrm{w} / \mathrm{v}) ; \mathrm{KH}_{2} \mathrm{PO}_{4}, 0.1 \% ; \mathrm{MgSO}_{4} \cdot 7 \mathrm{H}_{2} \mathrm{O}$, $0.05 \%$; ammonium sulfate, $0.5 \%$; $\mathrm{MnSO}_{4} \cdot 7 \mathrm{H}_{2} \mathrm{O}, 2 \mathrm{mg} /$ liter; $\mathrm{ZnSO}_{4} \cdot 7 \mathrm{H}_{2} \mathrm{O}, 2 \mathrm{mg} / \mathrm{liter} ; \mathrm{FeSO}_{4} \cdot 7 \mathrm{H}_{2} \mathrm{O}, 1 \mathrm{mg} /$ liter; $\mathrm{CuSO}_{4} \cdot 5 \mathrm{H}_{2} \mathrm{O}, 50 \mu \mathrm{g} / \mathrm{liter}$; thiamine- $\mathrm{HCl} 1 \mathrm{mg} /$ 
liter; and tap water. During the fermentation, the medium-pH was automatically controlled with $28 \%$ ammonia water.

Analytical methods. Citric acid and $d$-isocitric acid were assayed by the method described in the previous report. ${ }^{21}$ Polyol was also analyzed with the aqueous phase obtained by centrifugation of the culture broth by the method described in the previous report. ${ }^{1}$ ) Determination of phosphate was performed by the method of Chen et al. ${ }^{3}$

Measurement of intracellular pH of yeast cells. Intracellular $\mathrm{pH}$ of yeast cells were determined by the method of Conway and Downey described in the previous report. ${ }^{\text {s) }}$

Preparation of cell free extracts. All the operations were carried out at 0 to $4^{\circ} \mathrm{C}$. The cultured broth was centrifuged at $3,000 \times g$ for $20 \mathrm{~min}$. The cells existed both in the precipitate and in the residual $n$-alkane phase were collected on a filter paper to remove the residual $n$-alkane as much as possible and then washed three times with $0.05 \mathrm{M}$ Tris-HCl buffer ( $\mathrm{pH} 7.5$ ) containing $1 \mathrm{~mm}$ of mercaptoethanol. Washed cells were disintegrated by a ultrasonic generator KMS-250 (Kubota Seisakusho, Japan) at $0^{\circ} \mathrm{C}$ for $30 \mathrm{~min}$ at $10 \mathrm{kc}$. Cell homogenate was ultracentrifuged at $25,000 \times g$ for $40 \mathrm{~min}$ at $0^{\circ} \mathrm{C}$. The clear middle phase was collected carefully with a syringe. The cell free extracts thus obtained were used as the enzyme sources without further purification.

Enzyme assays. All spectrophotometric determinations were performed at room temperature in quartz cuvettes of 1-cm light path with a Hitachi spectrophotometer (139 type). The reduction of D-erythrose or $D$-fructose was measured by the method desribed in the previous report.5) The determination of transaldolase activity was performed by measuring the formation of glyceraldehyde 3-phosphate from fructose 6-phosphate and erythrose 4-phosphate. Glyceraldehyde 3-phosphate is determined by the combined action of triose phosphate isomerase and $\alpha$-glycerophosphate dehydrogenase. ${ }^{61}$ The reaction mixture contained in a total volume of $1 \mathrm{ml}: 25 \mu$ moles of Trismaleate buffer (pH 7.0); $0.5 \mu$ mole of fructose 6 phosphate; $0.5 \mu$ mole of erythrose 4-phosphate; 0.12 $\mu$ mole of NADH; $20 \mu \mathrm{g}$ of mixed crystals of triosephosphate isomerase and $\alpha$-glycerophosphate dehydrogenase and the enzyme to be tested. One unit of transaldolase is defined as the enzyme amount which catalyzes the decrease of $1 \mu$ mole of substrate per minute. Phosphogluconate dehydrogenase activity and glucose 6phosphate dehydrogenase activity were assayed according to the methods of Shimamura et al. ${ }^{7}$ and, of Brown and Wittenberger, ${ }^{8}$ respectively. One unit of the enzymes was defined as the enzyme amount whic catalyzes the increase in optical density $\left(A_{340}\right)$ of 0.0 per minute, Ribulosephosphate 3-epimerase activit was assayed by the method of Huritz and Horecker. One unit of the enzyme activity was defined as the er zyme amount which catalyzes the formation of $1 \mu \mathrm{mol}$ of ribulose 5-phosphate. Ribosephosphate isomeras activity was measured according to the method $\mathrm{c}$ Volk. ${ }^{101}$ One unit of enzyme was defined as the con version of $1 \mu$ mole of $D$-ribose 5 -phosphate to $D$ ribulose 5-phosphate in $1 \mathrm{~min}$.

Glucosephosphate isomerase activity was estimate by measuring the formation of the fructose 6-phosphat from glucose 6-phosphate according to the method o Reithel. ${ }^{111}$ One unit of enzyme was defined as th amount of the enzyme which catalyzes the formation o $1.0 \mu$ mole of fructose 6-phosphate per minute. Trans ketolase activity was measured by the method of Datt: and Racker. ${ }^{12}$ The assay mixture was made up a follows; $50 \mu$ moles of Tris- $\mathrm{HCl}$ buffer ( $\mathrm{pH} 7.5$ ), 2. ! $\mu$ moles of xylulose 5 -phosphate, $3.5 \mu$ moles of ribosi 5-phosphate, $0.2 \mu$ mole of thiamine pyrophosphate $2.0 \mu$ moles of $\mathrm{MgCl}_{2}$ and enzyme preparation $(0.1 \mathrm{ml}$. to a final volume of $1.0 \mathrm{ml}$. After incubation at $30^{\circ} \mathrm{C}$ for $10 \mathrm{~min}, 0.1 \mathrm{ml}$ of $50 \%$ trichloroacetic acid solutior was added to stop the reaction. Sedoheptulose 7-pho. sphate was assayed with $0.1 \mathrm{ml}$ of the supernatan according to the method of Dische. ${ }^{13)}$

One unit of enzyme was defined as the amount of enzyme which catalyzes the formation of $1.0 \mu$ mole of sedoheptulose 7-phosphate per $10 \mathrm{~min}$. Specific activities of the all enzymes were expressed as units pel milligram of enzyme.

Determination of protein. Protein was determined by the method of Lowry et al. ${ }^{141}$

Chemicals. D-Erythrose 4-phosphate, D-xylulose 5-phosphate, D-glucose 6-phosphate, D-erythrose, Dfructose, D-sedoheptulose 7-phosphate, disodium 6 . phosphogluconate, NAD, NADP, NADH and NADPH were all purchased from Sigma Chemical Corp., U.S.A. All other chemicals were of analytical reagent grade.

\section{RESULTS AND DISCUSSION}

Identification of reduction products of D-ery. throse and $D$-fructose by cell-free extracts

In order to ascertain that erythritol or $\mathrm{D}$ mannitol is formed by the reduction of erythrose or fructose, the following reactions were carried out. The reaction mixture containing sugars $(20 \mu$ moles $)$; Tris- $\mathrm{HCl}$ buffer (200 $\mu$ moles) pH 7.5; NADPH $(20 \mu$ moles $)$; and $0.2 \mathrm{ml}$ of enzyme preparation in a total volume of $2.0 \mathrm{ml}$ was incubated for $24 \mathrm{hr}$ at 
$30^{\circ} \mathrm{C}$.

For the identification of the product, the reaction mixture was deprotenized by the addition of $10 \%$ of zinc sulfate, adjusted to $\mathrm{pH}$ 7.5 with $0.6 \mathrm{~N}$ barium hydroxide, and then centrifuged. The supernatant solution was applied to paper chromatography as described in the previous report. ${ }^{1)}$ Reduction product of D-erythrose was clearly detected by spraying periodate-benzidine or alkaline silver nitrate, but was not reactive with anisidine. ${ }^{15)}$ $R f$-value of this spot in various solvent systems was identical with authentic mesoerythritol. Moreover, the reduction product of $\mathrm{D}$-fructose was also consistent with authentic D-mannitol in $R f$-value, color reaction and in optical rotation.

These results showed that Candida zeylanoides KY 6166 had potent enzyme activities to produce meso-erythritol and D-mannitol from the corresponding tetrose and hexose. However, as far as the above results were concerned, the specificity of dehydrogenase for the substrate seemed to be broad. Suzuki and Onishi, ${ }^{16}$ Verachtert and Dooms ${ }^{17}$ reoprted similar findings on the production of polyol from glucose by osmophilic yeast.

\section{Effect of $\mathrm{pH}$ on the activity of pentosephosphate} cycle enzymes

In the previous paper, ${ }^{5)}$ we showed that the intracellular $\mathrm{pH}$ in polyol-producing phase was about 5.5 5.7, but that in citric acidproducing phase was $6.5 \sim 6.7$. Thus, the change in intracellular $\mathrm{pH}$ in the above range resulted in the interconversion between citric acid fermentation and polyol fermentation owing to the remarked changes of the enzyme activities related to the biosynthesis of citric acid and polyols.

Therefore, the activities of enzymes involved in pentosephosphate cycle which played also a possible part in polyol synthesis were compared at various $\mathrm{pH}$ and the results are summarized in Table I. The activities of all enzymes tested were inhibited, more or less, at $\mathrm{pH}$ 5.5. Particularly transaldolase activity was affected most distinguishably. This result suggested that transaldolase could not take a part in polyol production which occurred preferentially at acidic $\mathrm{pH}$ (5.5 to 5.7 ). Venkalaraman and Racker also showed that transaldolase

Table I. Effect of pH on the Enzyme Activity Relating to Pentosephosphate

CYCLE IN Candida zeylanoides KY 6166

The right side column represented the optimal $\mathrm{pH}$ for individual enzyme activity.

$\begin{array}{ll}\mathrm{pH} & \text { buffer system } \\ 5.0 \sim 6.0 & \text { acetate buffer } \\ 6.0 \sim 7.0 & \text { Tris-maleate buffer } \\ 7.0 \sim 9.0 & \text { Tris-HCl buffer }\end{array}$

\begin{tabular}{|c|c|c|c|c|c|c|}
\hline \multirow[t]{2}{*}{ Enzyme } & \multicolumn{5}{|c|}{ Specific activity (units/mg protein) } & \multirow[b]{2}{*}{$\mathrm{pH}$ opt } \\
\hline & 5.0 & 5.5 & 6.0 & 6.5 & 7.0 & \\
\hline Transaldolase & 0.00 & 0.02 & 0.13 & 0.53 & 0.95 & 8.0 \\
\hline Transketolase & 0.28 & 0.32 & 0.38 & 0.43 & 0.69 & 7.7 \\
\hline $\begin{array}{l}\text { Glucose 6-phosphate } \\
\text { dehydrogenase }\end{array}$ & 15 & 23 & 32 & 41 & 55 & 8.2 \\
\hline $\begin{array}{l}\text { Glucosephosphate } \\
\text { isomerase }\end{array}$ & 0.39 & 0.50 & 0.72 & 0.85 & 1.30 & 8.0 \\
\hline $\begin{array}{l}\text { 6-Phosphogluconate } \\
\text { dehydrogenase }\end{array}$ & 8.0 & 18.1 & 21.1 & 27.0 & 35.5 & 8.3 \\
\hline $\begin{array}{l}\text { Ribulosephosphate } \\
\text { isomerase }\end{array}$ & 0.70 & 1.08 & 1.50 & 1.81 & 2.10 & 6.8 \\
\hline $\begin{array}{l}\text { Ribulosephosphate } \\
\text { 3-epimerase }\end{array}$ & 15 & 42 & 63 & 84 & 115 & 7.2 \\
\hline
\end{tabular}

The composition of the reaction mixture was described in MATERIALS AND METHODS except that buffer solutions of different $\mathrm{pH}$ were used. 


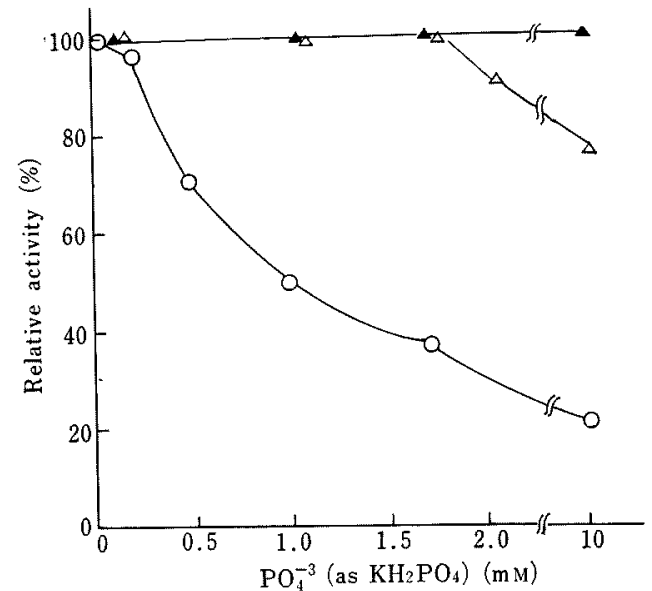

FIG. 1. Effect of Phosphate Ion on the Enzyme Activity in Candida zeylanoides KY 6166.

The composition of the reaction mixture was described in the text, except that phosphate ion was added as shown in the figure.

0 , transketolase; $\Delta$, glucose 6-phosphate dehydrogenase; $\boldsymbol{\Lambda}$, glucosephosphate isomerase.

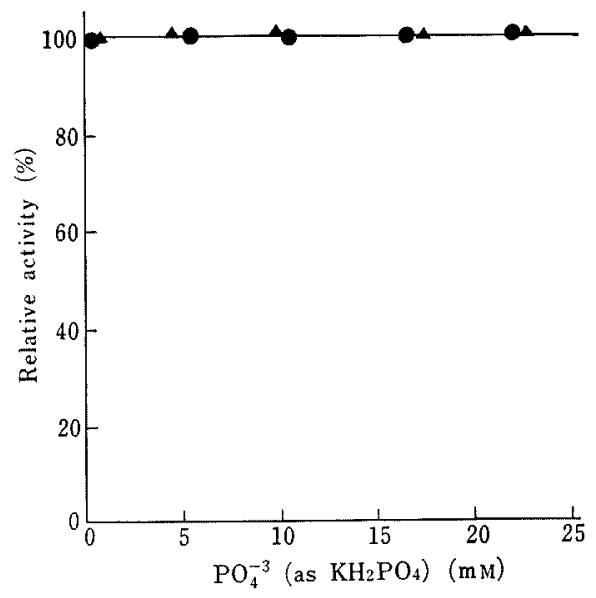

FIG. 2. Effect of Phosphate Ion on the Reducing Activity of D-Erythrose and D-Fructose in Candida zeylanoides KY 6166.

The composition of the reaction mixture was described in Materials AND METHOdS except that phosphate ion was added as shown in the figure.

$\boldsymbol{e}$, reducing activity of $\mathrm{D}$-erythrose; $\boldsymbol{\Delta}$, reducing activity of D-fructose.

activity in bakers' yeast was depressed at acidic $\mathrm{pH}(6.0 \sim 6.5)^{6)}$ Of the biosynthesis of erythritol from glucose, Spencer and Gorin demonstrated that the most possible reaction was implicated in transaldolase and trans-

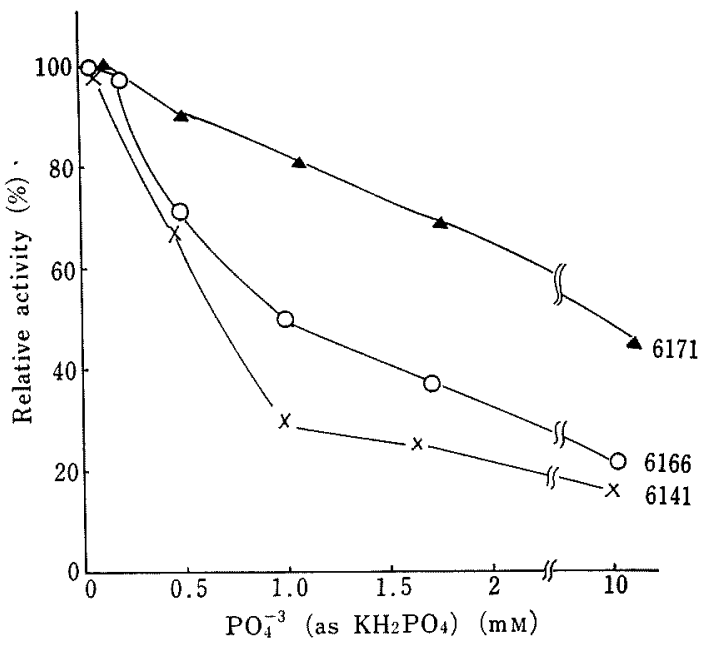

FIG. 3. Effect of Phosphate Ion on the Activity of Transketolase.

The composition of the reaction mixture was described in the text except that phosphate ion was added as shown in the figure.

0 , Candida zeylanoides KY 6166; $\times$, Candida lipolytica KY 6141 ; ^, Candida zeylanoides KY 6171.

ketolase via Emden-Meyerhof pathway. ${ }^{18)}$

On the other hand, the optimum $\mathrm{pH}$ of acid phosphatase catalyzing dephosphorylation of erythrose 4-phosphate and fructose 6-phosphate was 5.5 to 6.5 . Furthermore, the reduction activity of $\mathrm{D}$-erythrose and $\mathrm{D}$-fructose did not vary in the pH from 5.5 to $6.5 .^{5}$ )

Effect of phosphate ion on the enzyme activity relating to pentosephosphate cycle

In the previous paper, ${ }^{2)}$ we reported that the production ratio between erythritol and mannitol was remarkably affected by the concentration of phosphate in the medium. Keeping its concentration at high level (0.04 to 0.20 $\mathrm{mg} / \mathrm{ml}$ as $\mathrm{KH}_{2} \mathrm{PO}_{4}$ ), erythritol production was almost entirely converted to mannitol production. As described in the preceeding section, the alternation between erythritol fermentation and mannitol fermentation was assumed to depend on the synthetic rate between erythrose 4-phosphate and fructose 6-phosphate.

Thus the effect of phosphate ion on the activities of glucosephosphate isomerase, glucose 6-phosphate dehydrogenase and trans- 
ketolase, which mainly participated in the formation of erythrose 4-phosphate and fructose 6-phosphate were examined. The results are shown in Fig. 1. Activity of glucosephophate isomerase was not affected by phosphate ion in the wide range of its concentration, but glucose 6-phosphate dehydrogenase and transketolase decrease with the increase in phosphate ion concentration. Especially transketolase activity, which participated directly in the conversion of erythrose 4-phosphate and fructose 6-phosphate was reduced to about $50 \%$ wth $1 \mathrm{~mm}$ of phosphate ion. However, the inhibition of glucose 6phosphate dehydrogenase by phosphate ion was weak, as compared with the case of transketolase. On the other hand, the reduction activity of erythrose and fructose was not affected as shown in Fig. 2. Boyer et al. reported also that the transketolase activity in bakers' yeast was significantly depressed by phosphate ion. ${ }^{19}$ ) From all above results, it was reasonably concluded that the alternation between erythritol production and mannitol production by phosphate ion was caused by controlling the level of erythrose 4-phosphate and fructose 6-phosphate by the change of transketolase activity.

In order to clarify the effect of phosphate ion on the transketolase activity further, enzyme activity of other strains such as Candida lipolytica KY 6141 and Candida zeylanoides KY 6171, was measured as shown in Fig. 3. KY 6141 produced a large amount of mannitol associating with a small amount of erythritol under standard medium, but KY 6171 produced predominantly erythritol concomitantly with a small amount of mannitol. The transketolase activity in Candida lipolytica KY 6141 was significantly low level compared to that in
Candida zeylanoides KY 6171 under the same phosphate level. These results further supported that the conversion of erythritol and mannitol production was regulated by the activity of transketolase which was changed by the concentration of phosphate ion.

\section{REFERENCES}

1) K. Hattori and T. Suzuki, Agr. Biol. Chem., 38, 581 (1974).

2) K. Hattori and T. Suzuki, ibid., 38, 1203 (1974).

3) P. S. Chen, Jr., T. Y. Toribara and H. Warner, Anal. Chem., 28, 1756 (1956).

4) K. Hattori and T. Suzuki, Agr. Biol. Chem., 38, 1875 (1974).

5) K. Hattori and T. Suzuki, in press (1974).

6) R. Venkalaraman and E. Racker, J. Biol. Chem., 236, 1876 (1961).

7) M. Shimamura, J. Yoshitake and T. Imai, Agr. Biol. Chem., 37, 2245 (1973).

8) A. T. Brown and C. L. Wittenberger, J. Bacteriol., 106, 456 (1971).

9) J. Huritz and B. L. Horecker, J. Biol. Chem., 223, 993 (1956).

10) "Methods in Enzymology," Vol. IX, ed. by S. P. Colowick and N. O. Kaplan, Academic Press, New York, N. Y., 1966 p. 585.

11) ibid., p. 565.

12) A. G. Datta and E. Racker, J. Biol. Chem., 236, 617 (1961).

13) Z. Dische, ibid., 204, 983 (1953).

14) O. H. Lowry, N. J. Rosebrough, A. L. Farr and R. J. Randall, ibid., 193, 265 (1951).

15) D. S. Feingold, H. A. Neufeld and W. Z. Hassid, ibid., 233, 783 (1958).

16) T. Suzuki and H. Onishi, J. Ferment. Technol., 50, 844 (1972).

17) H. Verachtert and L. Dooms, Anatonie Van Leeuwenhoek, 35, Supplement, Yeast Symposium, I, 19 (1969).

18) J. F. T. Spencer and P. A. J. Gorin, Can. J. Biochem. and physiol., 38, 157 (1960).

19) "The Enzymes," Vol. 5, ed. by P. D. Boyer, H. Lady and K. Myrback, Academic Press, New York, N. Y., 1961, p. 397. 